\title{
Research on Employability of College Students Based on the Theory of Competency ---- A Case Study of Guangxi University
}

\author{
Fan WU ${ }^{1}$, Gui-Lan LIU ${ }^{2}$, Yu-Fei LI ${ }^{1}$ and Zhi-Yong TENG ${ }^{1}$ \\ ${ }^{1}$ Guangxi University, Nanning, Guangxi, China \\ ${ }^{2}$ Songgang Industrial Park, Foshan, Guangdong, China \\ *Email: gxwufan@163.com \\ *Corresponding author
}

Keywords: Competency, Employability of college students, Guangxi University.

\begin{abstract}
This paper is a case study of Guangxi University based on the theory of competency. Literature review, interviews with experts and questionnaire investigation are adopted to find that three groups of factors influence the employability of college students in three dimensions, i.e. professional skills, self-image and differential ability. These findings help build a structure model of employability of the college students, based on which, a questionnaire is designed. Upon analyzing the data from the recycled questionnaires, this paper reaches its conclusions and proposes countermeasures for and suggestions on developing college students that can meet the needs of the society and the market, with an aim to provide new ideas on solutions to part of employment problems of the college students.
\end{abstract}

\section{Introduction}

With the increasing number of graduates, college students have been facing more and more serious challenges in finding jobs. The employment of college students has become a problem concerning the people's livelihood in the country and a heated issue that has drawn wide attention from the society. There are both subjective and objective reasons for the difficulties of college students in finding jobs. Quite a few experts and scholars believe that a major one is their poor employability. Therefore, to develop and improve the employability of the college students is of great significance, for it is one of the effective approaches to increasing the employment rate of the students.

\section{Research Design and Process Steps}

\section{Selection and Extraction of Factors that Influence Employability of College Students}

Acquisition of the Group of Factors by Literature Review. One of the authors of this paper retrieves 97 papers with the key words of "employability of college students" from core journals on the "VIP Information", which is the largest comprehensive literature database in China. A group of factors (as named Group I, see Table 1) that affect employability of the college students are extracted, sorted out and then finalized. Times of the factors that are mentioned on these papers are counted by three categories, i.e. professional skills (20), self-image (33) and differential ability (27). 
Table 1. Group I of factors of employability of college students (data analyzed from literature review)

\begin{tabular}{l|l|l}
\hline Dimension & Factors & Frequency (in times) \\
\hline Professional skills & $\begin{array}{l}\text { Professional knowledge, professional skills, } \\
\text { competence in foreign language and computer, } \\
\text { academic understanding, professional quality, } \\
\text { qualification certificates }\end{array}$ & 20 \\
\hline Self-image & $\begin{array}{l}\text { Personality, sense of responsibility, } \\
\text { self-confidence, self-efficacy, psychological } \\
\text { quality, specialty, resilience in pressure, } \\
\text { attitude, sense of competition }\end{array}$ & 33 \\
\hline Differential ability & $\begin{array}{l}\text { Communication skills, adaptation to society, } \\
\text { occupational preferences, outlook on } \\
\text { employment, employment motivation, } \\
\text { occupation identity, teamwork, executive } \\
\text { capacity, innovation }\end{array}$ & 27 \\
\hline
\end{tabular}

Acquisition of the Group of Factors by Interviews. According to the research design, authors had interviews with 40 experts including government officials, teachers of the university who provide students with guidance on employment and HR managers of the enterprises, etc. on issues concerning employability of college students. The interviewees accepted our interviews in the forms of face-to-face talks, phone calls or e-mails in the last two months of 2013. Feedback from the interviewees was collected, sorted out and ranked by Excel. The top 10 factors that the interviewees mentioned most are named as Group II of factors of employability of college students (see Table 2). As Table 2 shows, the top 4 abilities that employers value most are practical ability, professional skills, communication skills and ability to adapt.

Table 2. Group II of factors of employability of college students (data analyzed from interviews)

\begin{tabular}{|c|c|c|c|c|c|}
\hline Rank & Factor & Frequency (in times) & Rank & Factor & Frequency (in times) \\
\hline 1 & Practical ability & 25 & 6 & Innovation & 16 \\
\hline 2 & Professional skills & 22 & 7 & $\begin{array}{l}\text { Self-position } \\
\text { ing }\end{array}$ & 13 \\
\hline 3 & $\begin{array}{l}\text { Communication } \\
\text { skills }\end{array}$ & 20 & 8 & $\begin{array}{l}\text { Qualificatio } \\
\text { n certificates }\end{array}$ & 11 \\
\hline 4 & Ability to adapt & 20 & 9 & Specialty & 11 \\
\hline 5 & $\begin{array}{l}\text { Sense of } \\
\text { Responsibility }\end{array}$ & 17 & 10 & $\begin{array}{l}\text { Occupationa } \\
\text { l Preference }\end{array}$ & 9 \\
\hline
\end{tabular}

\section{Prototype and Design of the Structure Model}

To select a model and to build a new one based on it is a vital step of this research. The relatively authoritative and applicable onion-like model of competency is selected as the prototype of the one for employability of college student, which is built with full consideration of the above-mentioned two groups of factors acquired by literature review and interviews. In accordance with the categories of Group I, the onion-like model of students' employability is divided in three dimensions, i.e. professional skills, self-image and differential ability (see Chart 1). 


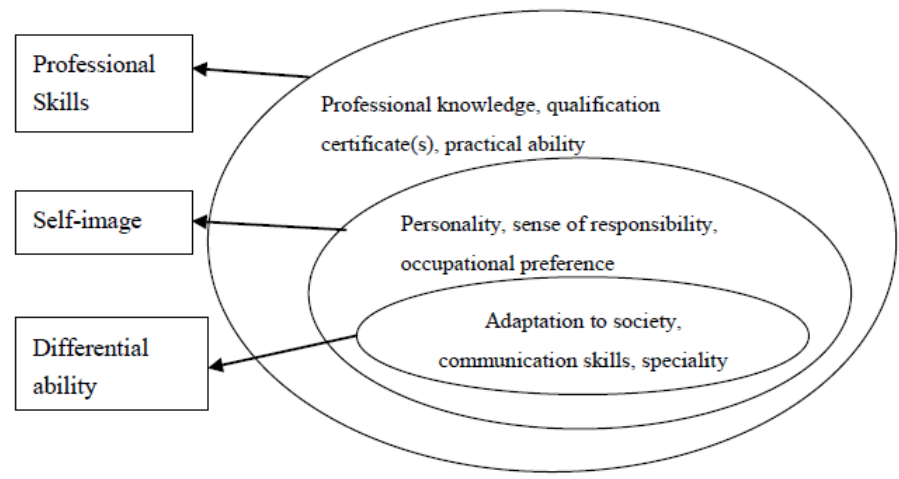

As Chart 1 shows, there are three tiers on the model. The outer one is professional skills, the middle, self-image and the inner, differential ability. It is easier for the college students to grasp professional skills, which is the fundamental employability, while it is harder for them to develop differential ability, the core. Professional skills include professional knowledge, qualification certificates and practical ability; self-image includes personality, sense of responsibility and occupational preference; and differential ability includes adaptation to society, communication skills and specialty.

\section{Distribution and Recovery of Questionnaires}

Sampling and Investigation Method. This paper takes students majoring in public administration at Guangxi University (GXU), China as the targets of the research. To ensure more representative samples, these students are divided into five groups, which are students enrolling in Guangxi University in 2010, 2011, 2012 and 2013 as well as graduates enrolling in 2008 or 2009.

As for investigation method, both paper and on-line questionnaires are distributed. Paper questionnaires are distributed to the students at college and one-line ones, to graduates and students who are not at school. Paper questionnaires are distributed by monitors in class, and the on-line ones are distributed with the assistance of graduates. Since the targets are graduates from GXU or students studying at the same university, there are fewer obstacles to the distribution and recovery of the questionnaires, which ensures the smooth investigation and guarantees the recovery.

Descriptive Statistics. 180 copies of paper questionnaires are distributed. Among them, 165 ones are recovered, with 155 ones being valid. 50 copies of on-line questionnaires are distributed. Among them, 38 ones are recovered, with 32 ones being valid. Altogether 230 copies are distributed, among which, 187 ones recovered were valid, accounting for $81.3 \%$ of the total. As Table 3 shows, the valid questionnaires are provided by 187 respondents, including 46 freshmen, 46 sophomores, 31 juniors, 43 seniors and 21 alumni that graduated from GUX 1 or 2 years ago. Among them, 50 respondents are boys, accounting for about $27 \%$, and 137 , girls, about $73 \%$.

Table 3. Descriptive statistics of the respondents

\begin{tabular}{l|lll}
\hline Respondents & No. of boys & $\begin{array}{l}\text { No. of } \\
\text { girls }\end{array}$ & Total \\
\hline Freshmen & 10 & 36 & 46 \\
Sophomores & 7 & 39 & 46 \\
Juniors & 11 & 20 & 31 \\
Seniors & 14 & 29 & 43 \\
Alumni who graduated 1or 2 years & 9 & 12 & 21 \\
ago & 50 & 137 & 187 \\
Total &
\end{tabular}


This paper also lists the types of the ideal employers of the respondents (see Table 4) and ranks them in a descending order as follow: state-owned enterprises (SOE), government departments, private enterprises, foreign-funded enterprises, taking postgraduate entrance exams and self-employment. $49.8 \%$ of respondents choose SOEs and government departments as their ideal employers, while only $6.6 \%$ of them choose self-employment,.

Table 4. Types of the ideal employers of the respondents

\begin{tabular}{l|llllll}
\hline $\begin{array}{l}\text { Type of } \\
\text { Employers }\end{array}$ & SOE & $\begin{array}{l}\text { Government } \\
\text { department }\end{array}$ & $\begin{array}{l}\text { Private } \\
\text { Enterpris } \\
\text { e }\end{array}$ & $\begin{array}{l}\text { Foreign- } \\
\text { funded } \\
\text { Enterpris } \\
\text { e }\end{array}$ & $\begin{array}{l}\text { Taking } \\
\text { postgraduate } \\
\text { entrance } \\
\text { exams }\end{array}$ & $\begin{array}{l}\text { Self- } \\
\text { employment }\end{array}$ \\
\hline Percentage (\%) & 28.2 & 21.6 & 18.4 & 16.9 & 8.3 & 6.6 \\
\hline
\end{tabular}

A cross-analysis is made for comparison between students' grades and their salary expectations (see Table 5). It is found that there are distinct differences of the students in different grade in salary expectations. Among the four items of salary expectation , as many as $56.5 \%$ of the freshmen expect to be paid more than RMB 4000 (USD 645 ) monthly; as for sophomores, juniors and seniors, many of them choose the item of RMB 3000-4000 (USD 484-645), with percentages of $43.5 \%, 45.2 \%$ and $48.8 \%$ respectively; as for alumni that graduated 1 or 2 years ago, $47.6 \%$ of them tick the item of RMB 2000-3000 (USD 323-484). The statistics show that since the second grade, under the guidance of the teachers of the university, more and more students are rational for salary expectations. They do not blindly pursue well-paid jobs any more. However, in general, students still hold high expectations on their salary.

Table 5. Cross-tabulation of grades and salary expectations

\begin{tabular}{l|llll}
\hline \multicolumn{1}{c|}{ Monthly salary } & $\begin{array}{l}\text { RMB 1500-2000 } \\
\text { (USD 242-323) }\end{array}$ & $\begin{array}{l}\text { RMB 2000-3000 } \\
\text { (USD 323-484) }\end{array}$ & $\begin{array}{l}\text { RMB 3000-4000 } \\
\text { (USD 484-645) }\end{array}$ & $\begin{array}{l}\geq \text { RMB 4000 } \\
\text { (USD 645) }\end{array}$ \\
\hline Grade 1 & $2.2 \%$ & $17.4 \%$ & $23.9 \%$ & $56.5 \%$ \\
Grade 2 & $0 \%$ & $23.9 \%$ & $43.5 \%$ & $32.6 \%$ \\
Grade 3 & $3.2 \%$ & $35.5 \%$ & $45.2 \%$ & $16.1 \%$ \\
Grade 4 & $0 \%$ & $34.9 \%$ & $48.8 \%$ & $16.3 \%$ \\
$\begin{array}{l}\text { Alumni that } \\
\text { graduated 1 or 2 }\end{array}$ & $0 \%$ & $47.6 \%$ & $33.3 \%$ & $19.0 \%$ \\
years ago & & & & \\
\hline
\end{tabular}

\section{Data Analysis}

\section{An Overall Evaluation on Employability}

How Deep Those Factors can Influence One'S Employability? Frequency is adopted to analyze the influence of the factors listed on the onion-like model of employability of college students (see Chart 2). On the whole, all of the factors have great influence on the employability, as evidenced by more than $40 \%$ of the respondents think so, and about $60 \%$ of them hold the same opinion of such factors as occupational preference, personality and sense of responsibility. This illustrates that the factors that this paper studies on have great influence on the employability. 


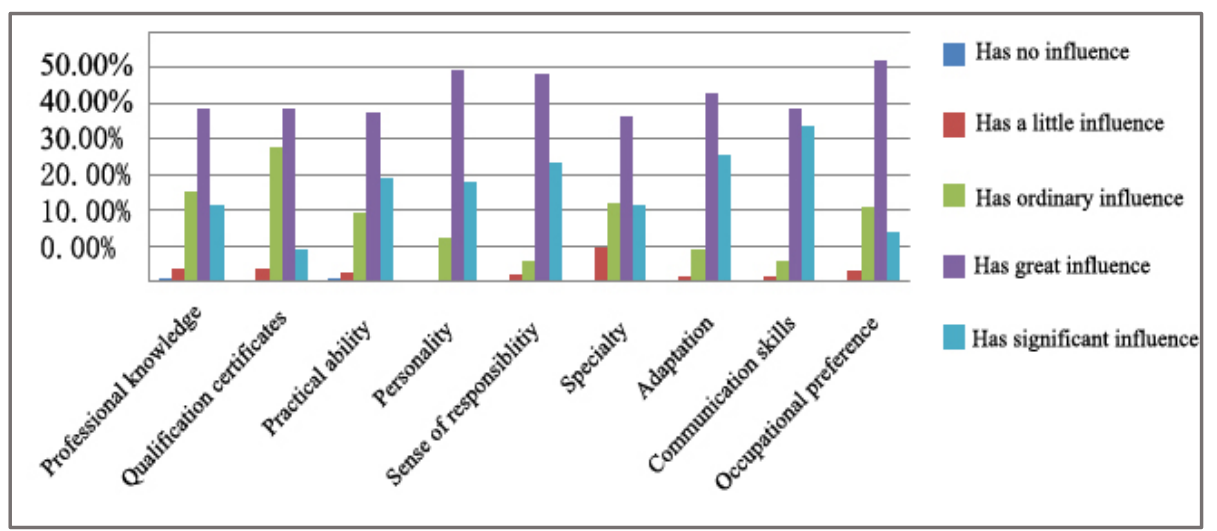

Chart 2. Thoughts of respondents on influence of the factors on employability?

Analysis on Gender Difference in Employability. Independent sample t-tests have been done to analyze the gender difference in employability (see Table 6), to see whether there are distinct differences between male and female respondents in their opinions of the importance to the factors. In the test, the factor that is believed to have significant influence on employability is scored 5; great influence, 4; ordinary influence, 3; a little influence, 2; and no influence, 1 . Factors with distinct difference, to be more specific, $\mathrm{P} \leq \alpha=0.05$ or $\mathrm{P} \leq \alpha=0.01$ will be marked with $\star$ or $\star \star$ respectively.

Hypothesis: $\mathrm{H} 0: \mu \mathrm{M}=\mu \mathrm{F} \longleftrightarrow \longrightarrow \mathrm{H} 1: \mu \mathrm{M}<\mu \mathrm{F}$ (Female respondents place more importance to the factors than male respondents do)

As Table 6 shows, the top 4 factors that the respondents pay most attention to are communication skills, sense of responsibility, adaptation and personality. A t-test has been done on each factor in two groups, i.e. male respondents and female respondents. It is found that there are distinct differences between male and female respondents in their thoughts on the influence of such factors as qualification certificates, specialty and adaptation $(\mathrm{P} \leq \alpha=0.05)$, to which the female respondents place more importance than the male respondents.

Table 6. Results of independent student t-tests on factors of employability

\begin{tabular}{|c|c|c|c|c|c|c|c|}
\hline Factor & $\begin{array}{l}\text { Mean of } \\
\text { male } \\
\text { respondents }\end{array}$ & $\begin{array}{l}\text { Mean of } \\
\text { female } \\
\text { respondents }\end{array}$ & Mean of all & Rank & $\mathrm{T}$ value & $\begin{array}{l}\text { P value } \\
\text { (single tail) }\end{array}$ & \\
\hline $\begin{array}{l}\text { Professional } \\
\text { knowledge }\end{array}$ & 3.84 & 3.86 & 3.85 & 6 & -0.125 & 0.451 & \\
\hline $\begin{array}{l}\text { Qualification } \\
\text { certificates }\end{array}$ & 3.41 & 3.70 & 3.56 & 9 & -2.437 & 0.008 & $\star \star$ \\
\hline Practical ability & 3.94 & 4.04 & 3.99 & 5 & -0.752 & 0.227 & \\
\hline Personality & 4.06 & 4.17 & 4.12 & 4 & -1.022 & 0.154 & \\
\hline $\begin{array}{l}\text { Sense of } \\
\text { responsibility }\end{array}$ & 4.14 & 4.24 & 4.19 & 2 & -0.925 & 0.178 & \\
\hline Specialty & 3.45 & 3.91 & 3.68 & 8 & -2.995 & 0.002 & $\star \star$ \\
\hline Adaptation & 4.06 & 4.28 & 4.17 & 3 & -1.883 & 0.031 & $\star$ \\
\hline $\begin{array}{l}\text { Communication } \\
\text { skills }\end{array}$ & 4.31 & 4.36 & 4.34 & 1 & -0.425 & 0.336 & \\
\hline $\begin{array}{l}\text { Occupational } \\
\text { preference }\end{array}$ & 3.82 & 3.88 & 3.85 & 6 & -0.527 & 0.300 & \\
\hline $\begin{array}{l}\text { Number of } \\
\text { samples (n) }\end{array}$ & 51 & 136 & 187 & & & & \\
\hline
\end{tabular}

Analysis on Grade Difference in Employability. One-way ANOVA has been adopted to investigate that how much importance that the students in different grades place to the employability (see Table 7), to see whether there is distinct difference. Before comparison, the factor that is believed to have significant influence is scored 5; great influence, 4; ordinary influence, 
3; a little influence, 2; and no influence, 1. Factors with distinct difference, to be more specific, $\mathrm{P} \leq \alpha=0.05$ or $\mathrm{P} \leq \alpha=0.01$ will be marked with $\star$ or $\star \star$ respectively.

As Table 7 shows, the top 4 factors that the respondents pay most attention to are communication skills, adaptation, sense of responsibility and personality. Respondents are divided into 5 groups by grades. One-way ANOVA is conducted on each of the factors to find out the F value. It is found that there are distinct differences of the respondents in different groups/grades $(P \leq \alpha=0.05)$ in their thoughts on the importance of such factors as practical ability, specialty and occupational preference. Respondents in Grade 4 and those graduated 1 or 2 years ago pay more attention to the three factors than those in lower grades.

Table 7. Results of one-way ANOVA on factors of employability

\begin{tabular}{l|l|l|l|l|l|l|l|l|l|l}
\hline Factor & Grade 1 & Grade 2 & Grade 3 & Grade 4 & Graduates & Total & Rank & F value & Pvalue & \\
\hline $\begin{array}{l}\text { Professional } \\
\text { knowledge }\end{array}$ & 3.96 & 3.74 & 3.65 & 4.05 & 3.81 & 3.86 & 7 & 1.484 & 0.209 & \\
\hline $\begin{array}{l}\text { qualification } \\
\text { certificates }\end{array}$ & 3.83 & 3.70 & 3.45 & 3.56 & 3.38 & 3.62 & 9 & 2.169 & 0.074 & \\
\hline Practical ability & 3.83 & 3.93 & 3.90 & 4.37 & 4.05 & 4.02 & 5 & 2.941 & 0.022 & $\star$ \\
\hline Personality & 4.13 & 4.04 & 3.94 & 4.33 & 4.29 & 4.14 & 4 & 2.168 & 0.074 & \\
\hline $\begin{array}{l}\text { Sense of } \\
\text { responsibility }\end{array}$ & 4.11 & 4.07 & 4.29 & 4.30 & 4.48 & 4.21 & 3 & 1.846 & 0.122 & \\
\hline Specialty & 3.80 & 3.80 & 3.26 & 4.05 & 3.95 & 3.79 & 8 & 3.920 & 0.004 & $\star \star$ \\
\hline Adaptation & 4.30 & 4.17 & 4.00 & 4.21 & 4.48 & 4.22 & 2 & 1.624 & 0.170 & \\
\hline $\begin{array}{l}\text { Communication } \\
\text { skills }\end{array}$ & 4.17 & 4.35 & 4.26 & 4.58 & 4.38 & 4.35 & 1 & 2.327 & 0.058 & \\
\hline $\begin{array}{l}\text { Occupational } \\
\text { preference }\end{array}$ & 3.74 & 3.91 & 3.52 & 4.07 & 4.14 & 3.87 & 6 & 4.708 & 0.001 & $\star \star$ \\
\hline $\begin{array}{l}\text { Number of } \\
\text { samples(n) }\end{array}$ & 46 & 46 & 31 & 43 & 21 & & & & & \\
\hline
\end{tabular}

\section{Analysis on Specific Factors of Employability}

Professional Skills. A cross-tabulation (see Chart 3) is used for analyzing the thoughts of the respondents on influence of professional skills on employability and whether they have improved their skills so as to find a good job. As Chart 3 shows, among the respondents that think the professional skills have great and significant influence on the employability, a majority of them have been improving their skills, and only a minority have already done, which illustrates that though students have realized the importance of professional skills, few of them take actions to do it. Lack of action is a prevailing problem. According to the frequency analysis on whether to improve their professional skills (see Chart 4 ), only $14.4 \%$ of the respondents have already done, while $85.6 \%$ of them are still working on it or planning to do but fail to improve. Professional skills is a fundamental ability that the students should grasp, among which, rich professional knowledge is important stepping stone for the students to find a good job. 
Chart 3. What do you think of the influence of professional skills on employability? v.s. have you improved your professional skills

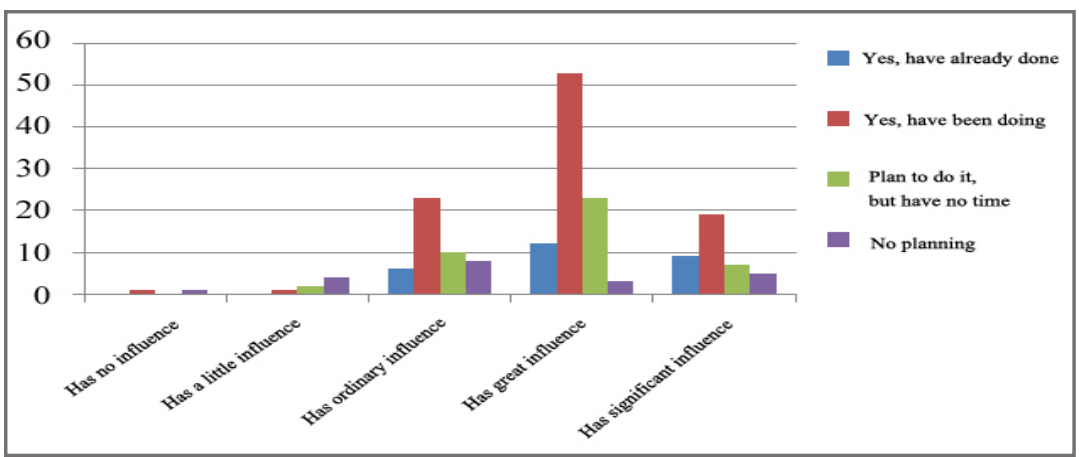

Chart 4. Have you improved your professional skills?

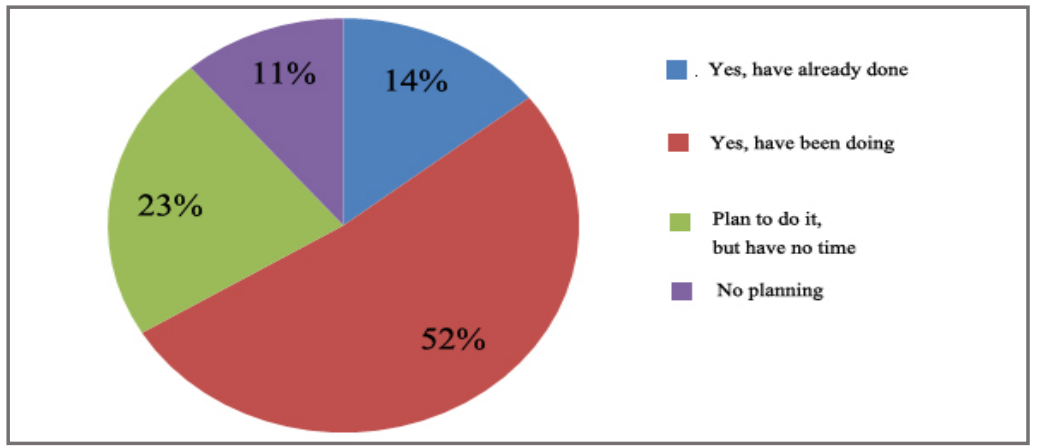

One of the reasons that taking exams for qualification certificates wins popularity among the students is the increasingly fiercer competition in the job market, as one more certificate means that the holder enjoys one more advantage. Cross tabulation is used for analyzing the influence of qualification certificates on employability and whether students have obtained relevant certificates (see Chart 5). As Chart 5 shows, a much larger proportion of respondents believe that qualification certificates have ordinary or great influence, among whom, about 50\% is preparing for the exams. In addition, according to a cross-tabulation of grades and the holders of qualification certificates, $72.1 \%$ of the seniors are qualification certificate holders, and $69.6 \%$ of freshmen, $82.6 \%$ of sophomores and $64.5 \%$ of juniors are in preparation for taking relevant exams, showing that most of the students value the role of qualification certificates.

Chart 5. What do you think of the influence of qualification certificates on employability? v.s. have you obtained relevant certificates?

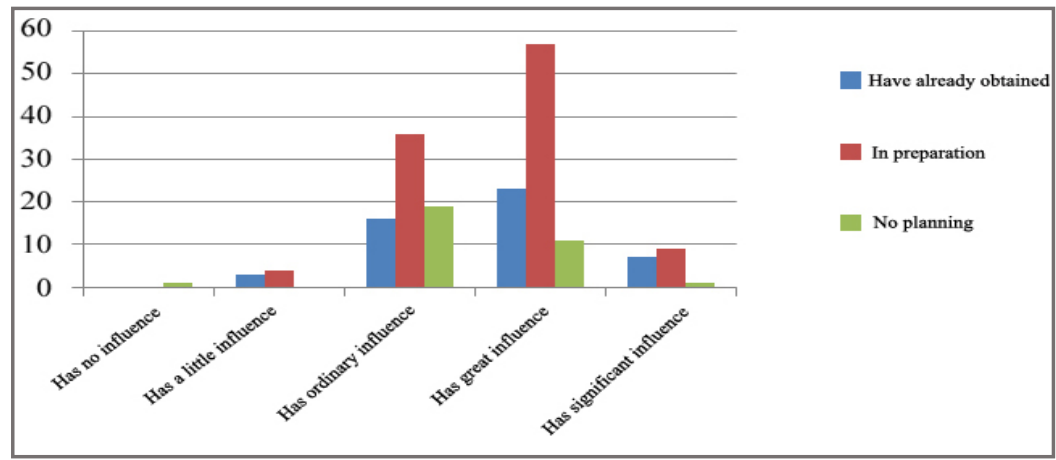

According to the results of interviews with experts, practical ability is considered the most important among all the factors of employability. Quite a few interviewees, however, reflect that lack of practical experience is a common problem of the graduate employees. When selecting and 
recruiting graduates, the employers prefer to hiring those with relevant internship experience under the same circumstances. One's practical ability is directly linked with quantity and quality of his/her social practice. Upon analyzing what social programs the students have joined in to improve their practical ability (see Chart 6), this paper finds that there are few types of the programs available for students to improve the ability. The types of these programs are limited and conventional. Besides, the students can hardly join in the whole process. All of these, from another side, reflect that universities should further work to providing more practice opportunities for the students.

Chart 6 . What activities and programs do you think can help improve your practical ability?

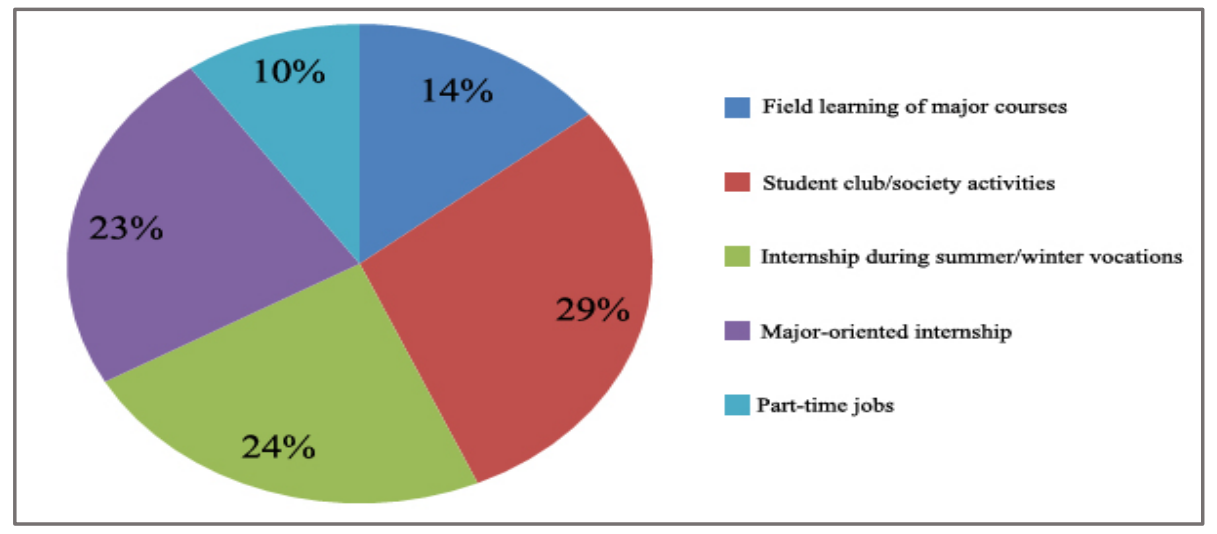

Self-image. Upon analysis, the correlation coefficient of one's personality and his/her confidence in finding jobs is 0.310 , and the $\mathrm{P}$ value is 0.000 , which confirm the correlation of the two. Cross tabulation is used for analysis on personality and confidence (see Chart 7). It is found that those respondents with outgoing or moderate personality are more confident than those introverted respondents in finding jobs. The results show that one can have more confidence in finding jobs by improving his/her personalities and prove the importance of the factor of personality in the structure model.

Chart 7. What's your personality? v.s. are you confident in finding jobs?

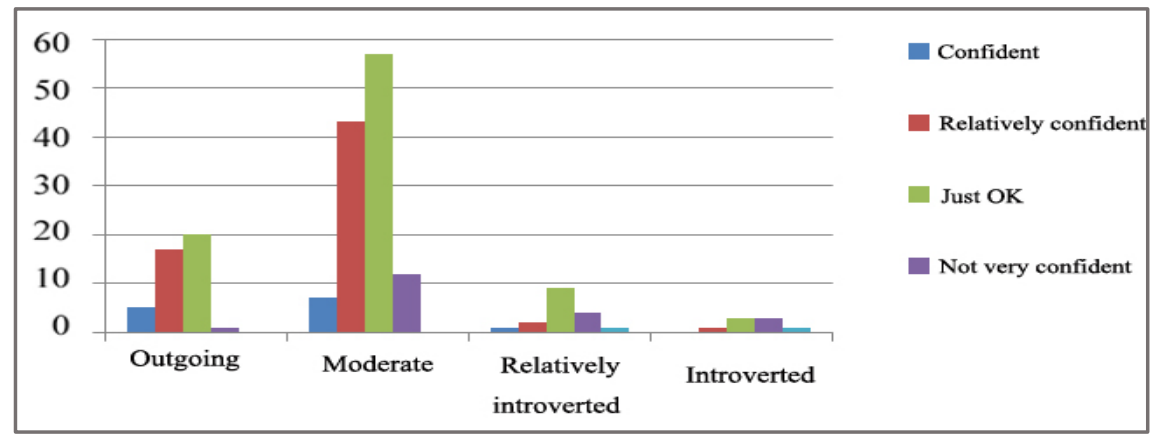

The sense of responsibility is that students are aware of the responsibilities that they should take in the development of the society and themselves. As China has been campaigning to promote the core values of socialism, importance of the sense of responsibility is unarguable. After cross tabulating the influence of the sense of responsibility on employability and students' self-evaluation of the sense of responsibility (see Chart 8), it is found that most of the students think that this factor has great or significant influence on employability, and a majority of them think they have strong sense of responsibility. The results show that, in general, students have strong sense of responsibility, which also demonstrates that Chinese universities have achieved outcomes in guiding the students to set correct values and to be more responsible. 
Chart 8. What do you think of the influence of sense of responsibility on employability? v.s. what do you think of yours?

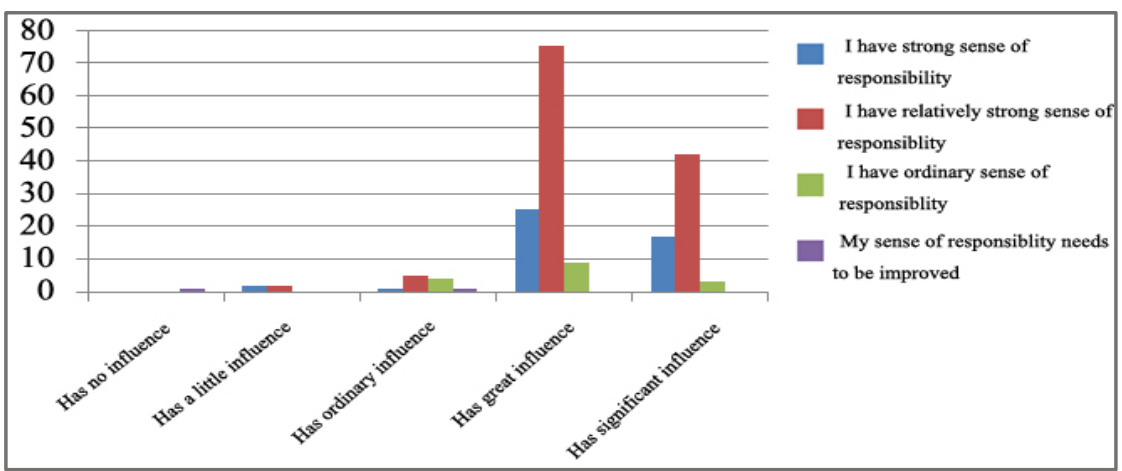

Self-image includes occupational preference, which can be most directly reflected by the choice that one makes when selecting jobs. This paper analyzes the choice frequecy of the students in selecting different types of jobs (see Chart 9). In the society that worships money, the most frequent choice of the respondents is "The job I like", followed by "The job well paid", showing that the students are rational in employment, know what they want, and pay attention to personlized development.

Chart 9. What kind of job will you choose?

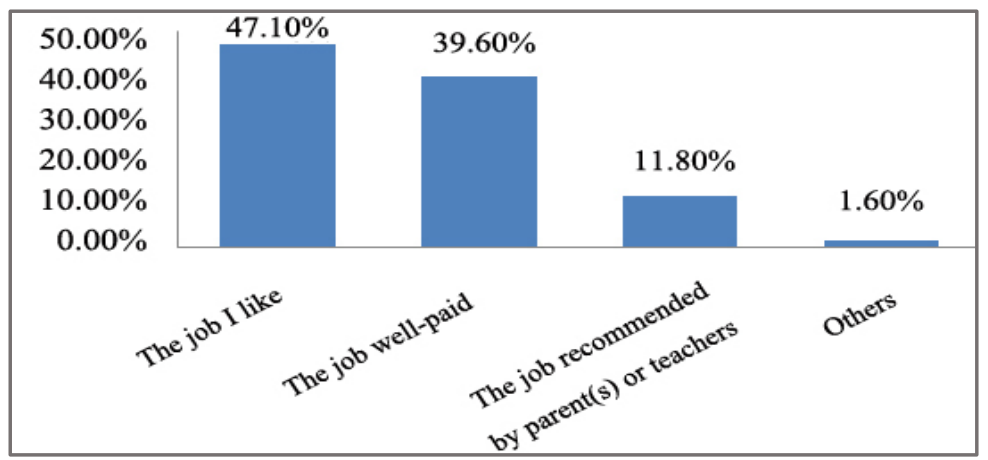

Differential Ability. Differential ability, which includes adaptation to society, communication skills and specialty, is the core competitiveness of the graduates in employment. This paper analyzes the students' ability to adaptation to the society (see Chart 10 ), and finds that $21.4 \%$ of the respondents believe that they can well adapt to the society; $69 \%$ of them can ordinarily adapt to and then basically adapt to after a short period adjustment; and only $5.9 \%$ do not believe that they can adapt to the society. The results show that the students, in general, are able to adapt to the society, which should be attributable to the guidance of the university, for example, arranging relevant programs and activities.

Chart 10 How do you think of your adaptation to the society?

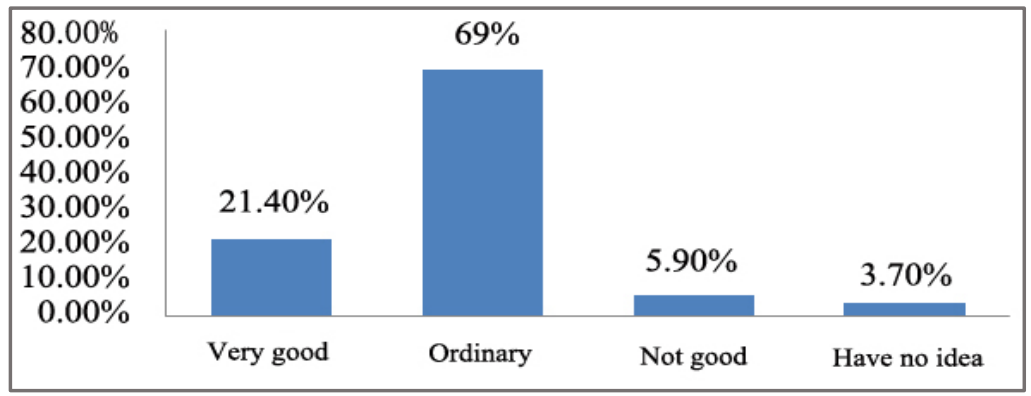


Only strong professional skills and profound knowledge cannot guarantee smooth employment to the graduates. Good communication skills are also very important, which is one of the abilities that the employers value most. Graduates with good communication skills can allow the employers to better understand their comprehensive ability, thus to enhance their own competitiveness. What's more important, they can better develop interpersonal relations, exploit their potential and be more capable of their future jobs. However, with analysis on communication skills of the respondents (see Chart 11), it is found that $52.9 \%$ of them think their communication skills are ordinary; only $4.8 \%$, strong; and $10.7 \%$, poor. The results show that the students, in general, are ordinary in communication skills, which should be further improved.

Chart 11. How do you think of your communication skills ?

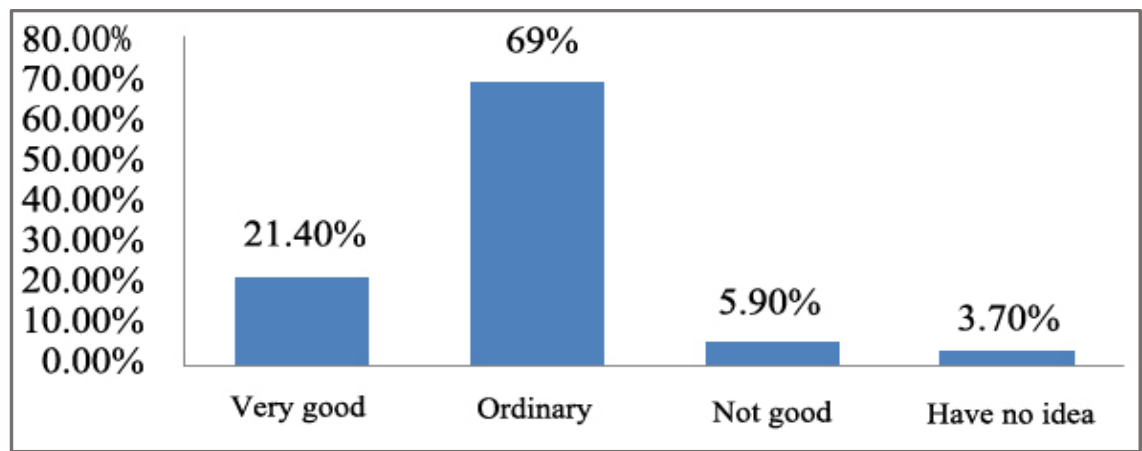

Nowadays, personalized development is advocated in the society and employers are increasingly inclined to hiring those gratduates with specialties. Apart from professional skills and practical ability, one's specialty and hobby, as part of his/her comprehensive quality, are also considered as one of the assessment items by the employers. Cross tabulation is used for analyzing the throughts of respondents on influence of specialty on employability and whether they take specialty trainings (see Chart 12). It is found that that $67.9 \%$ of the respondents think speciatly is of great or significant influence on employability, which shows that students are fully aware of the importance of specialty. However, it is a shame that only $17.1 \%$ of them took trainings to develop thier specialty before, and $47.1 \%$ of them express their willings to take such trainings but fail because they have no time or money, which demonstrates that the students lack actions to do it. Besides, the university does not pay enough attention to developing the speciality of the students, for it fails to provide proper conditions for the students to do so. 
Chart 12. What do you think of the influence of specialty on employability v.s. do you take speciality training(s)?

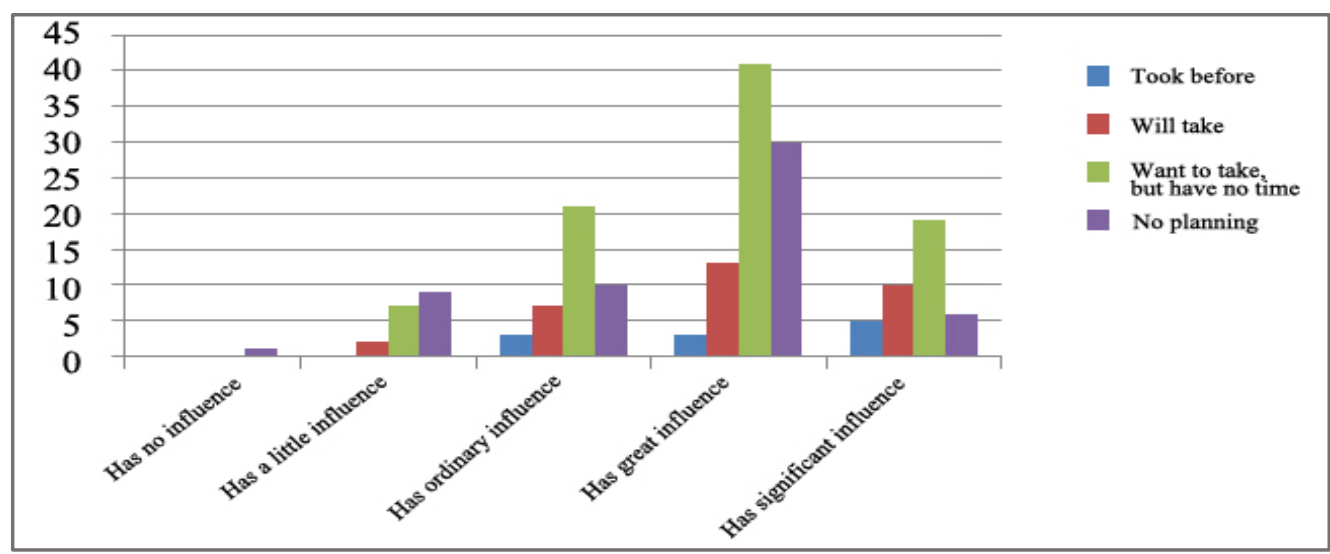

\section{Research Conclusions, Countermeasures and Suggestions}

\section{Research Conclusions}

The research shows that the structure model of employability of college students includes professional skills, self-image and differential ability in three dimensions. There are three factors under each dimension. Professional skills: professional knowledge, qualification certificates and practical ability; self-image: personality, sense of responsibility and specialty; differential ability: adaptation to society, communication skills and occupational preference. According to the above-mentioned analysis results, this paper draws conclusions as follows: 1 ) college students hold high expectations on salary; 2) students are well aware of how to improve their employability but lack actions; 3) students of different gender and in different grades have different understanding on what factors of employability influence more; 4) outgoing personality can help students improve their employability; and 5) students should still work hard to improve their practical ability and communication skills.

\section{Countermeasures and Suggestions}

From the Angle of Governments. Firstly, the governments should deepen the structure reform. College students, in general, lack social practice. Governments should improve the university-enterprise cooperation mechanism and tax preference policies, so as to encourage governments, public institutions/organizations and enterprises to provide the students with more practice opportunities, and to institutionalize and regulate the internship and social practice of the students. As the research of this paper shows, $6.6 \%$ of respondents are interested in self-employment. Governments should establish and improve relevant supporting systems, for example, to release more incentives to encourage the employment of college students, self-employment in particular. Secondly, the government should better construct the job market for graduates and to create a fair and just environment for them to find jobs. In the survey, quite a few respondents reflected that they were in the face of unfair competition including gender discrimination and backdoor deals. Therefore, governments should invest more efforts to regulate and supervise the labor market and eliminate unfair competition, to ensure the development of an orderly market with standards. Thirdly, the governments should actively build various platforms and national systems for developing students' employability and specify the connotations and structure of the employability, thus to set standards for the universities and students to improve it and help the former adopt measures accordingly. Fourthly, the government should build and improve a system for monitoring dynamic of employability and establish communication mechanisms to share information on the rational flow of personnel and supply of and demand for human resources. To accurately obtain the information on graduate employability in a scientific manner is possible only if the monitoring system has been built and improved. The governments 
should make full use of various statistics, data and research reports to establish and improve the communication mechanisms.

From the Angle of Universities. Firstly, universities should show great initiative in adapting to the changes of the market. The training mechanisms should be established and improved based on meeting the needs of the market. When arranging training courses or programs, universities should focus more on improving students' employability that can allow them keep pace with the changing society, instead of teaching them something cliché. Secondly, universities should provide the students with more guidance on employment and optimize the services in this regard. To develop the employability of the students is a systematic project, which should be included into the syllabus of the course concerned. The contents and goals of the training should be specified in the syllabus of each semester and a whole set of guidance on employment should be provided for the students, including career planning, professional quality training, consulting services, relevant assistances and recommendation of graduates to employers, etc. Thirdly, universities should arrange more diversified training programs to improve the students' employability. Universities should combine curricular/extracurricular activities with employability training programs, cooperate with enterprises to establish various practice/internship bases to provide students with more opportunities to gain job experience, and arrange diversified programs, including community activities, volunteer programs, contests and student society activities, to improve students' employability. In addition, universities should open more elective courses and encourage students to select the courses in line with their occupation positioning but not for the pure purpose of gaining credits. Fourthly, universities should exchange information more timely. Universities, the employment departments in particular, should enhance contacts and communication with the external bodies including employers, intermediary agencies and alumni offices, etc. to open up channels to obtain information on job vacancies. Schools should follow the latest research results made by experts and scholars on employment tendency and students' employability and pay attention to the policies on employment released by the central government, thus to be aware of how to develop and improve the employability of the students step by step.

From the Angle of Students. Firstly, students should be responsible for developing and improving their own employability. In the job market with fierce competition, stronger employability, to a large extend, could be decisive for a graduate to find a better job. Therefore, a precondition for the students to improve their employability is that students should pay enough attention to it and be responsible for themselves. Secondly, students should have a better cognitive understanding of the society and have a right outlook on employment. Students' inappropriate expectations on employment are directly caused by their vague cognition of the society. That's why many students, on one hand, fail to get those well-paid jobs and, on the other hand, are unwilling to do those less-paid jobs. The outlook on employment is a key factor of the career positioning, and a major one that impacts the behavior of students as interns and job hunters [1]. Students should open up more channels to obtain information on employment in the real society. Thirdly, students should make career planning and set goals for self-development of employability accordingly. As mentioned before, to develop and improve the employability of students is a complicated project involving different parties. As for the students, "freshmen should know themselves; sophomores should narrow and then finally find out the occupation that they are really interested in; juniors should improve their professional quality; and seniors should finish a preliminary transformation from a student to an employee [2]." Students should make their career planning and set clear goals and positioning as early as possible, and adjust them in line with the needs of the market.

\section{References}

[1] J.K. Li, Research on relations between employability and job hunting behavior of college students, Peking University Press, Beijing, 2013, p138. 
[2] D.S. Lai, Capital investment effect of human resources on employment difficulties of graduates, Peking University Education Review, 2004, 6(4):13-15

[3] Weinert P., Baukens M., Bollerot P, Gapenne M.P \& Walwei U., Employability: from theory to practice (Chinese version translated by Guo R.Q.), China Labour and Social Security Publishing House, Beijing, 2004

[4] L.J. Jia, Xu Y., Psychological analysis on employability of college students, Education Research, 2006 (10)

[5] Z.Y. Xie, Thoughts on training of employability of college students, Education Research, 2005 (01)

[6] Y. Wang, Research on relations between outlook on employment and employability of college students and their job performance, Hangzhou, 2006 